\title{
Holocene fluvial valley fill sources of atmospheric mineral dust in the Skeleton Coast, Namibia
}

\author{
David S.G. Thomas ${ }^{1,2,3 \star}$, Julie A. Durcan ${ }^{1}$, Andrew Dansie ${ }^{1}$ and Giles F.S. \\ Wiggs ${ }^{1}$
}

${ }^{1}$ School of Geography and the Environment, University of Oxford, Oxford OX1 3QY, UK ${ }^{2}$ Geography, Archaeology and Environmental Studies, University of the Witwatersrand, Johannesburg, South Africa

${ }^{3}$ Department of Environmental and Geographical Science, University of Cape Town, Rondebosch, South Africa

*Corresponding author david.thomas@ouce.ox.ac.uk

\section{Abstract}

Western Namibia is a significant global source of atmospheric mineral dust. We investigate the relationship between dust and source sediments, assessing the sustainability of dust flux. Remote sensing studies (Vickery and Eckhardt, 2013) have highlighted specific ephemeral fluvial systems as important contributors to dust flux, including highlighting sections of valleys that are the origins of dust plumes in the period 2005-8. Little is known however about the specific within-valley dust sediment sources, particularly whether dust is derived from modern ephemeral channel floors or older valley fill sediments, many of which have been reported in the region (Stone and Thomas, 2013). As part of a region-wide analysis of aeolian dust flux, we investigate the sediment properties of atmospheric dust samples and valley sediments from the Huab valley, one of the principal regional dust sources. Trapped dust samples contain up to $88 \%$ very fine sand and silt when collected samples are disaggregated prior to analysis. Valley fill surface samples comprise $80 \%$ very fine sand and silt, and the surface of the modern ephemeral channel $30 \%$. Valley fill sediments were sampled at depths up to $3.6 \mathrm{~m}$ below the present surface and reveal This article has been accepted for publication and undergone full peer review but has not been through the copyediting, typesetting, pagination and proofreading process which may lead to differences between this version and the Version of Record. Please cite this article as doi: $10.1002 /$ esp.4151 
Holocene depositional ages from $0.6 \pm 0.03 \mathrm{ka}$ back to $9.79 \pm 0.73 \mathrm{ka}$. These sediments contain $30 \%$ to $6 \%$ very fine sand and silt, with levels decreasing with depth and age. Aeolian bedforms in the valley system (nebkhas on the fill surface and climbing dunes on valley margins) indicate that aeolian processes under the influence of strong seasonal easterly winds likely result in dust being winnowed out of the valley fill surfaces, with sandy bedforms being constructed from the coarser component of the fill sediments. The volume of valley fill sediment suggests dust sourced from Holocene sediments is likely to continue into the future regardless of flow conditions in the modern channel system.

Key words: mineral dust valley fill Holocene aeolian Namibia

\section{Introduction}

The drylands of southern Africa are a major source of atmospheric mineral dust in the southern hemisphere. However, the landscape units from which dust is sourced are highly discrete. The large palaeolake basins of Etosha in Namibia (Hipondoka et al., 2006) and Makgadikgadi in Botswana (Burrough et al., 2009) are the primary sources of southern African seasonal dust emissions today (Bryant 2003, Bryant et al., 2007, Bhattachan et al., 2015). Physically smaller sources, including salt pans and river valleys, are now also identified as significant contributors to dust flux in the region (Eckardt and Kuring, 2005). These are usually in the form of low level plumes that are identifiable in MODIS and SeaWiFS imagery but not in observational systems such as TOMs, that have tracked higher level plumes and their terrestrial sources (Legrand et al., 2001). 
Most significant amongst the smaller-scale sources are the ephemeral valley systems of the northwest Namibian coastal zone (Vickery and Eckardt 2013). The twelve valleys (Figure 1) include the Tsondab and Tsauchab, which trend east-west into, and terminate within, the Namib Sand Sea; the Kuiseb, which forms the northern boundary of the sand sea; and a series of valleys from Swakopmund northwards to the Angolan border that are sourced in the Great Escarpment mountains and run east-west across the Skeleton Coast hyperarid zone to the Atlantic Ocean.

General associations have been drawn between fluvial controls and dust emissions in a wide range of environmental contexts, where water can at different times either inhibit dust entrainment or supply the sediment for deflation (Prospero et al., 2002). Over longer time scales $\left(\sim 10^{3}-10^{5}\right.$ years), it can be posited that the major global palaeolake dust sources, such as the Bodélé Depression in Chad, may be supplylimited in terms of their ability to emit dust, regardless of favourable atmospheric conditions (Engelstaedter and Washington 2007), because dust is sourced from sediments deposited during wetter late Quaternary phases (e.g. Warren et al., 2007) which is finite in volume.

In southern Africa, marine sediment core records from the SE Atlantic Walvis Ridge (Stuut et al., 2002) have been interpreted as indicating that both precipitation and windiness have controlled levels of dust flux over the last 300ka. The highest volumes of ocean dust deposition occurred during glacial rather than interglacial times, controlled at $10^{3}-10^{4}$ year timescales principally by the strength of easterly winds rather than precipitation levels in source areas (Stuut et al., 2002). At shorter 
time scales it may be possible to establish links between fluvial sediment supply and dust emission events. For example, over a twenty year observational period, Bryant (2013) identifies antecedent flooding as a source of sediment input that acts as a positive control on dust flux emissions from Sua Pan, Makgadikgadi. In a study of dust emission events from the Kuiseb Valley, Namibia, in the period 2005-2008, Vickery and Eckardt (2013) posited a link between ephemeral flow events and subsequent aeolian dust emission.

The last two decades have seen significant advances in the science of mineral dust emissions, with Vickery and Eckardt (2013) proposing that dust emissions from any source are consequential to its exact regional setting. There remain however considerable data gaps in both the atmospheric and surface control aspects of aeolian emission. Allied to the field data collection component of a major research programme focussed on generating the first dust source-area process data tailored to climate modelling needs ${ }^{1}$ (Haustein et al., 2015), a series of ongoing investigations are providing new data from Namibian dust-emitting valleys on the relationships between source sediments and dust production (e.g. Dansie et al., $2017 \mathrm{a}$ and b). This paper contributes a further component to this programme, investigating the depositional age of fluvial fills in one of the most heavily monitored systems, the Huab Valley, to address questions of the temporal origins of valley sediments, associations between dust flux and valley deposits, and whether dust flux is ultimately supply-limited. To do this we use both sedimentary data from modern dust and valley sediments, and 2) optically stimulated luminescence (OSL) age data

\footnotetext{
${ }^{1}$ DO4Models: http://www.geog.ox.ac.uk/research/climate/projects/do4models/
} 
derived from the fluvial valley fill deposits that are exposed through channel incision in the valley (Figure 2).

\section{Background}

\section{Skeleton Coast valley systems and fluvial sediments}

Today the geomorphic dynamics of the east-west orientated Skeleton Coast valleys are dominated by aeolian processes; evident from nebkha dunes (Figure 3) and wind scour on valley floors, climbing dunes and drapes on valley sides. These valleys are also regionally-significant sources of aeolian dust. Annually, dust plumes (Figure 1) during easterly Berg wind events (which primarily occur in winter months, AprilSeptember) extend over the Atlantic Ocean to the west of the Skeleton Coast (Vickery and Eckardt, 2013, Dansie et al., 2016 a and b). Ephemeral fluvial flow occurs in the valleys, driven by summer month (DJFM) precipitation events in the inland escarpment source areas that may exceed $200 \mathrm{~mm}$ mean annual rainfall (Stone and Thomas 2013), but with high interannual variability.

Evidence of more significant fluvial flow regimes in the past is provided by extensive valley fill sediments. In some valleys these have been the subject of chronometric investigations and interpretations in the context of late Quaternary changes in precipitation regimes. Dated sequences (summarised in Stone and Thomas, 2013) come from the Khumib, Hoarusib, Hoanib, Kuiseb and Tsauchab valleys (Bourke et al., 2003; Brook et al., 2006; Eitel et al., 2005, 2006; Srivastava et al., 2004, 2005, 2006; Stone et al., 2010) but not the Huab. Various accumulation phases for valley 
sands and silts have been placed within the c130 ka-0.4 ka period with the majority occurring within the last $40 \mathrm{ka}$ (Stone and Thomas, 2013). Difficulties have ensued in ascribing palaeoclimatic and palaeoenvironmental interpretations to many of these deposits, with some studies attributing silt-sand accumulation to drying conditions (e.g. Marker and Muller, 1978), and others to wetter events (e.g. Srivistava et al., 2006). In part, differences arise because sediments are found in a range of environmental contexts within the valleys, with locational, sedimentary and structural characteristics of deposits now providing a greater interpretive capacity (Stone and Thomas, 2013). Deposits in more westerly locations in the valley systems are generally slack-water features, indicative of greater flow than under the more semiarid conditions of today (e.g. Srivastava et al., 2004, 2005, 2006). Deposits in upvalley (eastern) locations are more indicative of flow incompetence, low-energy runoff, and limited transport capacity under drier conditions (e.g. Eitel et al., 2005). In some situations, these sediments may also be associated with valley-slope loess units (Brunotte et al., 2009).

Individual sedimentary units require careful interpretation with respect to the valley context in which they occur. In this regard, Grodek et al. (2014) used a palaeohydrological approach to investigate valley deposits along a 150km stretch of the middle Kuiseb valley. Their analysis, based on sedimentary data and luminescence dating, identified over forty flood events leading to accumulation during the last 1300 years, but with century and decadal scale phases of increased flood frequency also identified. Using a similar approach, Greenbaum et al. (2014) recorded a similar number of flood event deposits in the Swakop valley, but with accumulation spanning a much longer period, back to $15 \mathrm{ka}$. Within this record, data 
are interpreted to suggest that flood magnitudes were at their highest during the transition from warm, dry conditions to the colder and wetter Little Ice Age (700-200 years ago) and in the late $19^{\text {th }}$ to early $20^{\text {th }}$ centuries.

\section{Dust flux and sources}

It was noted earlier that data on Namibian dust flux comes at two distinct scales:

millennial scale records from oceanic sink data (Stuut et al., 2004) and event-scale remote sensing-derived data for recent decades (e.g. Vickery et al., 2013) that can link dust events to specific source locations. It is this latter approach that has highlighted the Namibian valleys as major dust sources, with 111 plume events from 39 source locations identified from MODIS imagery for the three years from 2005 through to 2008 (Vickery et al., 2013). In terms of frequency, these represent a third of the total plumes emitted from southern Africa during that period, with the Huab system being one of the major emitting source areas, with 15 plumes in $2005-8$ (Vickery, 2010). Nine of these plumes were sourced from a small section of the lower valley, which forms the focus of our subsequent analyses.

Absent to date are data on the sedimentological characteristics of dust-event sediments, and of associated valley deposits. Dansie et al. (2017a and b) show that the surface sediments of the Huab system are neither homogenous in sedimentology or in their susceptibility to deflation. Therefore, to establish the relationship between the aeolian and fluvial sediment systems, further data on dust sedimentary properties and from fluvial valley fills, are required. These data, along with information on the age of fluvial deposits, can provide the basis for a more holistic 
understanding of the relationships between fluvial and aeolian sediments in the valleys and on the temporal origins of the material that is being deflated today. In this paper we present data to test these relationships and to address the question of the sustainability of dust flux from the valley systems. We do this specifically in the context of the Huab system, which in 2013 was subject both to field monitoring of dust events and the sediments associated with these events, and to sampling of the valley floor sediments themselves for sedimentary and depositional age determinations. During the 2013 survey season nine notable dust flux events were observed from the section of the valley investigated in this paper, on 1, 2 and 5 May, 11 and 17 of June, and 21, 22, 25 and 30 July. The largest events, in terms of duration and magnitude were those of 5 May, and 21 and 30 July.

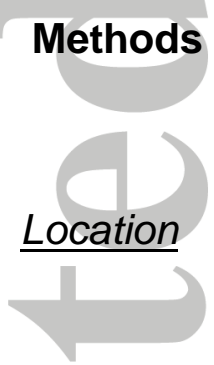

The Huab valley extends for $\mathrm{c} 300 \mathrm{~km}$ from the central Highlands of Namibia, through the Great Escarpment (Morin et al., 2009), and flows southwest to the Skeleton Coast, where the channel enters the Atlantic Ocean at $20.910^{\circ} \mathrm{S}, 13.451^{\circ} \mathrm{E}$ via a small delta. The catchment has an area of $14800 \mathrm{~km}^{2}$, the seventh largest of the 12 west coast valley systems, and mean annual precipitation through the system ranges from up to $345 \mathrm{~mm}$ in the east, where altitudes reach almost $1600 \mathrm{~m}$ asl, to almost zero at the coast; $80 \%$ of the catchment receives less than $100 \mathrm{~mm}$ precipitation (Jacobson et al., 1995, Figure 1). The lower c70 km of the Huab valley is set largely within Karoo (Permo-Carboniferous to Jurassic) glacial sedimentary and volcanic 
units that form valley sides that can be variable but steep and several hundreds of metres high above the channel floor. Part of the system follows ancient glacial channels (Jacobson et al., 1995) which form the broad valley (up to $2 \mathrm{~km}$ wide) in which more recent valley fill deposits have accumulated. The middle and upper catchment primarily lies in the metamorphic and igneous rocks, largely granites and gneisses, of the 2 bil yr PreCambrian Kamanjab inlier, set within the Damara

\section{Orogen.}

\section{Field sampling}

Field monitoring stations recording environmental and meteorological data were established at six locations in the lower c30 km of the Huab valley, the section of the system where valley fills have accumulated and from where many dust plumes are sourced (Vickery, 2010). Monitoring station data were collected during the period April-September 2013. This included Big Spring Number Eight (BSNE) aeolian sediment samplers (Zobeck et al., 2003, Mendez et al., 2011) to capture horizontal sediment flux at $0.25 \mathrm{~m}$ (sampler 1), $0.47 \mathrm{~m}$ (sampler 2), $0.89 \mathrm{~m}$ (sampler 3 ) and $1.68 \mathrm{~m}$ (sampler 4) above the ground surface. These heights were selected to replicate the heights of anemometers in the meteorological station equipment arrays. At these six locations, and additional sampling points through the full length of the Huab system (see Dansie et al., 2017a and b), surface samples were collected in transects across the valley to include valley fill and modern channel sediments. The remainder of this paper utilises data from site $\mathrm{H} 2$ (Figure 2) and its immediate vicinity. 
Monitoring Station H2 (Figure 2) was located in one of the widest parts of the Huab valley system, $21.3 \mathrm{~km}$ from the channel mouth at $20.865^{\circ} \mathrm{S} 13.653^{\circ} \mathrm{E}$. Alluvial sediments extend across the $1100 \mathrm{~m}$ wide valley floor, upstream from a topographically-induced narrowing of the valley that has acted as a barrier to flow, leading to the extensive accumulation of sediments. The surface of the valley fill shows significant evidence of aeolian activity, in the form of nebkha dunes accumulated around occasional shrubs, and wind scour features. The modern channel has incised into the valley fill, exposing up to $4 \mathrm{~m}$ of fill sediments in the channel sides (Figure 3). A secondary channel is further incised into the main meandering channel system, exposing a further $1.1 \mathrm{~m}$ of sediments of a secondary inner fill.

A transect across the valley floor at $\mathrm{H} 2$ collected surface samples (c200 $\mathrm{g}$ each) for particle size and nutrient content from 10 points that embraced the valley fill surface S1 S2 and S3 in Figure 2), $10 \mathrm{~cm}$ subsurface of the valley fill (S4), inner channel terrace (S5, S6) and the modern channel floor (S7, S8, S9, S10) (Dansie et al., 2017a and b). Samples collected for OSL dating from sites Huab13/1 and Huab13/2 also provided subsamples for particle size analyses through the vertical exposures in the main valley fill and the inner fill (Figure 3). Sediment trapped in the BSNE samplers was emptied on a monthly basis (Dansie et al., 2017c) and provided data on the characteristics of the sediment mobilised in dust-raising events in 2013.

Samples from the transect and BSNEs were collected in pre-weighed ziplock sample bags. Nine samples for OSL dating were collected in light-proof $15 \mathrm{~cm}$ long capped black plastic tubes, which were additionally wrapped in black plastic bags. 


\section{Sedimentary analyses}

Grain size analyses were undertaken using a Malvern Mastersizer Hydro 2000MU to determine sample particle size ranges of the different sedimentary units in the valley and to identify the proportion of fine material that might be susceptible to aeolian erosion. Samples were 'dry'-analysed (with no disaggregation and measured in air) following drying and riffling to less than $4 \mathrm{~g}$ to meet equipment specifications and to standardise the subsamples derived from the different units included in the study. A further subset of samples were also measured 'wet', after standard preparation for disaggregation by digesting overnight in $\left(\mathrm{NaPO}_{3}\right)_{6}$ and four hours on a horizontal shaker before being analysed in the wet dispersal unit to establish the finer silt-sized material present as aggregates within samples. We analysed particle size in both dry and wet dispersion modes for several reasons. While it is desirable to measure sediments 'as found', this condition may not represent particle size distributions 'as deposited'. This applies not just to valley fill sediments that may have been resident for long time periods (centuries to millennia) but also to sediment collected in BSNE samplers. These sediments are salt and mineral-rich (Dansie et al. 2017a and c) and the western region of Namibia is greatly affected by coastally-derived fog that can blow inland for tens of kilometres. Thus some BSNE samples when collected were damp and cohesive, not the state in which they would have been windtransported. Additionally, saltation bombardment during transport can disaggregate finer particles, which can then reaggregate on collection. Given these considerations and notwithstanding the observations of Keiser et al. (2014) on the effects of laboratory methods on particle size distributions, it was considered appropriate to 
use both dry and wet measurement techniques, as the wet data gives an indication of the potential to provide fine material for deflation.

\section{Age determinations}

Samples for OSL dating (Figure 3) were opened and prepared under subdued orange light conditions at the Oxford Luminescence Dating Laboratory, University of Oxford. Sediments were treated with hydrochloric acid and hydrogen peroxide to remove carbonates and organic matter, and sieved to isolate either the $125-150$ or the $180-210 \mu \mathrm{m}$ grain size fraction. Heavy liquid density separation was carried out to isolate quartz grains and the resulting material was etched using hydrofluoric acid to remove the alpha-irradiated outer surface of the quartz grains and any non-quartz mineral grains still present.

All OSL measurements were made using a Risø TL/OSL luminescence reader. OSL was stimulated using green light-emitting diodes $(525 \mathrm{~nm})$ and detected through a bialkali photo multiplier tube fitted with $7.5 \mathrm{~mm}$ U340 filters. Equivalent dose $\left(D_{e}\right)$ measurements were made following the single-aliquot regenerative dose (SAR) protocol (Murray and Wintle, 2000; Wintle and Murray, 2006), using a preheat of $220^{\circ} \mathrm{C}$ for $10 \mathrm{~s}$, a cut-heat of $160^{\circ} \mathrm{C}$ for $0 \mathrm{~s}$, and luminescence was measured at $125^{\circ} \mathrm{C}$ for $100 \mathrm{~s}$. Small aliquots of sample were used and a standard set of rejection criteria (e.g. Jacobs et al., 2006) was applied, including the OSL IR depletion ratio of Duller (2003) and the fast ratio of Durcan and Duller (2011) adjusted for stimulation with green diodes. Final $D_{e}$ determinations were calculated using the central age 
model (Galbraith et al., 1999) or finite mixture model (Galbraith and Green, 1990), depending on the calculated overdispersion value, after Rodnight et al., (2006). The environmental dose rate was calculated using radionuclide concentrations measured using inductively coupled plasma mass spectrometry, which were converted to dose rates using the attenuation factors of Guerin et al., (2011) and corrected for attenuation by grain size, chemical etching and a moisture content of $5 \pm 2 \%$. The dose rate contribution from cosmic rays was calculated according to Prescott and Hutton (1994). All dose rates were calculated using the DRAC (v1.1) program of Durcan et al. (2015), available at www.aber.ac.uk/alrl/drac.

\section{Results}

\section{Sedimentary data}

Dry -analysis particle size data are presented in Table 1 and 2 and Figure 4. Data are mean values for contexts where multiple samples were collected (e.g. the fill surface values in Table 1 and Figure 4 are the means of samples S1, S2 and S3). Aeolian dust is often considered to equate to silt-sized material $(2-63 \mu \mathrm{m})$ but commonly it includes particles up to $\sim 100-150 \mu \mathrm{m}$ in diameter (e.g. Hesse and McTainsh, 1999, Wiggs et al., 2003). Grain size data in Tables 1 and 2 are therefore categorized to include the 'very fine sand' and 'fine sand' classes. Medium and coarse sand do, however, also play a function in dust generation, as saltation triggers the expulsion of finer material into the atmosphere (e.g. Rice et al., 1996) during entrainment events, and can break-up protective surface crusts by bombardment. 
Figure $4 \mathrm{a}$ and $\mathrm{b}$ show that the dry-analysed samples from the valley fill sediments largely display comparable grain size profiles, with distribution curves peaking around $200 \mu \mathrm{m}$. Some variability occurs; samples from the modern channel floor are coarser than those from the fill surface, with a modal peak around $350 \mu \mathrm{m}$, while the modern fill surface is bimodal in distribution with a second coarser peak at over 1 $\mathrm{mm}$ particle diameter. The finer limbs of the two curves (up to the $\mathrm{c} 100 \mu \mathrm{m}$ modal peak) are directly comparable, but the greater contribution to the total curve of the coarser component of the surface sample likely reflects a residual lag component resulting from sediment loss through deflation. The BSNE data for the three dates that collectors were emptied (Table 1) are plotted in Figure 4c. These show that modal values, regardless of sampling date, peak in the $80-100 \mu \mathrm{m}$ size range, with both an increase in the modal value and an increasing contribution of medium and coarse sand as height of the trap descends: i.e. the peaks skew to the right of the graph as sampler height decreases This reflects a greater contribution of saltation, rather than suspended, load closer to the ground surface.

Notwithstanding the commonality in the modal peaks of the majority of samples from the vertical channel bank sections, the data do show some internal variability through the profile (Figure 3b). Sample Huab13/1/2 is bimodal with a secondary peak at 1500 $\mu \mathrm{m}$, and sample $13 / 1 / 6$ is significantly coarser than the others, lacking a silt component and peaking at $600 \mu \mathrm{m}$. These differences may reflect different sediment loads at separate times of fill deposition; they may however also simply reflect variability within the sedimentary lenses and laminae constituting the units in the section as a whole (Figure 2a). 
Table 2 shows that the transported aeolian sediments that contribute to dust flux from the valley comprise both silt and very fine sand fractions with the silt component not exceeding $22 \%$. Dry analysis data show that the upper fill sediments comprise no more than $7 \%$ silt (Table 1). Only samples Huab13/1/1, 13/1/2 and 13/2/1 in the vertical section samples contain a silt component (Table 1); the remaining units comprise solely sand-size sediment.

Given the low silt content of the dry-analysed sediments, three samples from the main vertical valley fill section representing upper, middle and lower components (samples Huab13/1/1,1/3 and 1/6) and the fill surface sample were subjected to wet grain size analysis, to investigate the presence, in aggregate form, of material finer than sand within the valley and BSNE trap samples (Table 3). Figure $4 d$ shows how on disaggregation, all samples reveal a greater proportion of fine-grained material, with modal peaks of valley fill samples diminishing in height in the 200-500 $\mu \mathrm{m}$ range and more significant limbs in the finer particle sizes emerging.

These data show a significant silt content within both the surface sediment samples and the valley fill samples. When very fine sand and silt contents are considered together, as the potential suspended load (data in right hand column of Tables 1 and 3 ), the potentially available dust content in valley fill samples increases from $21.22 \%$ to $30.82 \%$ (Huab13/1/1), $7.91 \%$ to $18.58 \%$ (Huab13/1/4), and even Huab13/1/6, which had no silt or very fine sand in dry analysis samples, increases to a content of $5.93 \%$. There is clearly a potential future dust load in deeper valley fill sediments, though with variability through the unit. 
The collected surface samples also show significant fine sand and silt content increases after disaggregation and wet analysis. This component of the valley-fill surface sample rises from $33.03 \%$ to $79.74 \%$, with significant increases evident in the silt + very fine sand content of samples at all locations (Table 3). Interestingly, the silt + very fine sand content of the BSNE samples also increases after disaggregation in analysis, more than doubling (33.18\% rising to $69.46 \%)$ in the case of the lowermost sampler, BSNE 1, and from $75.27 \%$ to $88.44 \%$ in the uppermost sampler, BSNE 4.

\section{Age of Huab valley fills}

OSL age data are presented in Table 4 and shown in Figure 3. In addition to $D_{e}$ analysis, dose recovery tests were undertaken on samples Huab13/1/1, 1/6 and $13 / 2 / 1$ and the ratio of the given to recovered dose was $0.93 \pm 0.03,0.95 \pm 0.02$ and $0.95 \pm 0.04$ respectively, demonstrating the suitability of the SAR protocol for $D_{e}$ measurement. In general, OSL signals measured from this suite of samples were reasonably bright (e.g. Figure 5a) and dominated by the fast component in the initial part of the signal (e.g. Durcan and Duller, 2011). Using the calculations of Heer et al., (2012), the small aliquots used in this study are estimated to consist of $\sim 65$ grains per disc, and single grain analyses of samples Huab13/1/1 and -13/2/1 show that $2-3 \%$ of grains give a luminescence signal detectable above reader background levels. Therefore, the signal from each aliquot is expected to originate from 1-2 grains on average, which is sufficient for the detection of heterogeneity in the dose distributions. For this suite of samples, overdispersion between $14 \%$ and $98 \%$ is 
observed (Table 4), and overdispersion is greater than $37 \%$ for all but one sample. Attributing the cause(s) of scatter in dose distributions is challenging, and multiple depositional and post-depositional factors may contribute to the observed heterogeneity in $D_{e} s$, including incomplete bleaching (e.g. Olley et al., 1998), microdosimetric variability (e.g. Murray and Roberts, 1997) and bioturbation mixing (e.g. Bateman et al., 2003). Given the geomorphological setting, with the sediments likely deposited following transport in flashy desert flow events, heterogeneous bleaching is likely to contribute significantly to the observed spread in data, and the finite mixture model has been used to identify the well-bleached component in the dose distributions.

The calculated OSL ages indicate phases of deposition of alluvial valley fill sediments during the Holocene (Table 4). At site 1, the upper unit dates to within the last millennia, with ages of $0.73 \pm 0.07 \mathrm{ka}$ and $0.60 \pm 0.03 \mathrm{ka}$ for samples Huab13/1/1 and 13/1/2.. Age increases with depth throughout the rest of the sequence and the OSL dating demonstrates that the majority of the sediments observed have been deposited since the mid-Holocene, with sample Huab13/1/5 towards the base of the unit dated to $4.41 \pm 0.32 \mathrm{ka}$. Sample Huab13/1/6 at the base of the unit was deposited at $9.79 \pm 0.73 \mathrm{ka}$. At site two, samples Huab3/2/1 and $13 / 2 / 2$ give ages of $0.62 \pm 0.04 \mathrm{ka}$ and $0.67 \pm 0.06$ ka respectively, correlating with the upper part of the sequence at S1. The deepest sample taken from S2, Huab13/2/3, is dated to $1.39 \pm 0.10 \mathrm{ka}$, suggesting the deposition of the valley fill sediments of this unit within the past 1500 years. 


\section{Discussion: Sediment supply in the Huab valley and implications for dust emissions}

In the Kuiseb valley, modern dust emissions show a temporal relationship to antecedent flood events (Vickery and Eckardt, 2013). We interpret the Huab data and field observations during times of aeolian activity during the field season as showing that modern dust emissions in the Huab valley are associated with valley fill sediments that accumulated in the Holocene and not the narrow channels that experience ephemeral fluvial flow today. Further field investigations in other dustemitting valleys in the area will be needed to establish if this is in fact the situation throughout the region. There is ample very fine sand and silt-size material in these deposits, and significant geomorphic evidence of sediment movement by the wind on the fill surfaces at elevations above the modern ephemeral channel. The incised lower channel displays some evidence of modern fluvial flow, but not of significant deposition of new silt-sized sediments derived from upper valley locations.

The OSL chronology of the valley fill sediments does however indicate that, in the last $10 \mathrm{ka}$ at least, deposition in this section of the valley has occurred on multiple occasions. These are likely to be slack water deposits, observed in other Namibian valley contexts (e.g. Srivastava et al., 2004), and this is supported by the fine laminae within the fill sediments and the valley context, upstream from a pinch point in the valley that would act as an impediment to flow, encouraging reductions in transport velocities and subsequent sedimentation. The sedimentary unit appears to extend across the valley at this location, which would also support the notion that ponding has occurred, but confirmation would require supporting data from additional 
locations in the sedimentary fill. Sections of other Namibian west coast valleys show evidence of complex depositional histories and of cut and fill accumulations (e.g.

Grotek et al., 2014). While it requires more detailed field survey to fully ascertain the nature of deposition in this wide, flat valley fill location, exposures within the sides of the incised channel tend toward supporting, in this specific part of the Huab system, deposition in slack water conditions. This may also have been important for the accumulation of fine sands and silts, the material that is critical for aeolian dust supply.

The oldest sediments exposed in the channel bank section, based ona single age, date to $9.79 \pm 0.73 \mathrm{ka}$, but there appears to be no further sedimentary preservation of depositional events until $4.41 \pm 0.32 \mathrm{ka}$. The hiatus in ages between samples $13 / 1 / 6$ and $13 / 1 / 5$ may represent a real absence of deposition, spatially variable deposition not recorded at this location, or erosion, likely by deflation of materials in the $c 5$ kyear period between the ages. Comparable within-errors early Holocene ages are recorded in the accumulated units in the more northerly upper Hoanib catchment $(9.4 \pm 0.7 \mathrm{ka}$, Eitel et al., 2006), and the terminal deposits of the more southerly Tsauchab (9.1 \pm 1.0 and $9.0 \pm 1.6$ ka, Brook et al., 2006). The Hoanib also records accumulation at $4.9 \pm 0.4 \mathrm{ka}$.

After $4.4 \mathrm{ka}$, depositional events could be interpreted as occurring with a c.1200 year frequency (Figure 2a) with rounded mean ages $3.2 \mathrm{ka}, 2 \mathrm{ka}$ and $0.7 \mathrm{ka}$ in section Huab13/1. The upper two ages (13/1/2 and 13/1/1) at $0.73 \pm 0.07$ ka and $0.60 \pm 0.03$ ka are not within one sigma errors, although this needs to be interpreted with caution given the high overdispersion values (Table 4). If these ages were to represent 
distinct depositional events, then either the frequency of accumulation in the last 700 years has changed from earlier millennia, or the ages from sediments lower in the section are not totally representative of the apparently bounded units that they are derived from. That is, other ages may be derived from within these units were more samples collected for dating. In this respect, the problems reported from aeolian sands by Leighton et al., (2013) with using bounding surfaces as distinct event boundaries may warrant some consideration as relevant to the interpretation of desert fluvial deposits and their depositional chronologies.

Placing these deposits in a regional context, Greenbaum et al. (2014) record several accumulation events in the last millennium within Swakop valley fluvial deposits, including at $0.74 \pm 0.19$ and $0.74 \pm 0.09 \mathrm{ka}$. In the Kuiseb valley, Grotek et al. (2014) report dated flood deposits at $0.67 \pm 0.04 \mathrm{ka}$ and $0.65 \pm 0.04 \mathrm{ka}$ within a millennial record of major flood events occurring every 20 to 40 years. These studies suggest that deposits from other floods during the past 1000 years are likely to be recorded within this extensive Huab valley fill unit.

The sediments from the finely laminated inner fill, within the meander of the current Huab channel, were interpreted in the field as representing a second fill phase within the channel incised into the valley-wide deposits. The ages derived from 13/2/1 and $2 / 2$ are almost identical to that of $13 / 1 / 2$ suggesting that these sediments are not a distinct fill within a cut but are part of the main depositional system.

Only the upper samples from both these vertical sections had a silt-sized component when particle size data were derived through dry sample analysis (Table 1), though 
very fine sand is prevalent through the deposits within the valley fill. On disaggregation of samples (Table 3), the proportion of silt size material increased significantly demonstrating that appropriate material for wind-suspended transport is available within valley fill sediments. There is variability of the fine content between samples (compare for example the data for Huab13/1/1 and Huab13/1/4). While this may reflect differences in the precise units sampled within the laminae in the fill, there is also the possibility that upper units are enriched by dust fall and infiltration of fines into the surface sediments, it can be noted here too that the fill surface and 10 $\mathrm{cm}$ depth samples have higher silt and very fine sand proportions than the deeper fill units. Indeed, disaggregation may occur during transport events through the effects of saltation bombardment.

The BSNE samples were also subject to dry and wet particle size analyses, with increases in the very fine sand and silt content following (Figure 4e). However, it is not possible to definitively determine from the wet and dry analyses of these samples the relative contributions of material transported as aggregates compared with material transported as silts and then subject to post-transport re-aggregation under moist atmospheric conditions. In this regard, the most notable difference between wet and dry data is for the sediment collected in the lowest sampler, BSNE 1. Here, dispersal and wet analysis results in a notable decrease in the coarser component. This we postulate indicates that the saltation load has a significant fraction that comprises aggregated silt-size particles. Figure $4 \mathrm{f}$ shows the wet analysed data for the valley fill dated sediments and the mean BSNE sampler data for each height. The coarser nature of the fill is evident, but the overlapping nature of the fill and 
collected dust data demonstrate the potential of the fill materials to provide material for deflation.

Overall, these analyses show that valley fills contain sufficient silt and very fine sand to act as a considerable source of material during deflation events. The silt captured in the BSNE traps is likely to be derived from the mechanical breakdown of aggregates within the sand-size component of the valley fill sediments, through the impact of saltating grains during aeolian transport events. Furthermore, the presence of silt at depth in the valley fills demonstrates the sustainability of this source of atmospheric mineral dust.

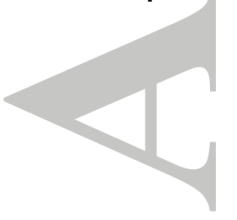

\section{Conclusions}

This paper has presented the first systematic study of modern aeolian dust flux source sediments, including consideration of their accumulation ages. The Namibian west coast valleys represent significant, focussed, sources of aeolian atmospheric dust. In this study, which has centred on the section of the Huab valley that is a major source of dust plumes observed in MODIS imagery, we provide evidence to support a strong relationship between dust sources and Holocene fluvial valley fills. Other aeolian bedforms in the valley system, including nebkha dunes on the valley fill surface and climbing dunes on valley margins, suggest that aeolian processes occurring under the influence of strong easterly winds generate local sandy bedforms and the emission of dust into the atmosphere. Given the minimum thickness (as exposed in the investigated channel section) of $c 4 \mathrm{~m}$ of valley fill sediments, the likelihood of many metres more beneath the modern channel level, 
and a record of fluvial depositional events in the mid-Holocene (indicated by the OSL ages), it seems likely that windblown dust events in the Namibian valleys will not be limited by sediment supply in the future. Indeed, our data suggest that the current supply of erodible sediment in the valley-fills would provide ample material to sustain a high frequency of windblown dust events even if fill replenishment events are centuries to millennia apart. This is despite the studied location not recording flood deposits more recent than c.600 years ago. Recent investigations (Grodek et al., 2014, Greenbaum et al., 2014) in two other western Namibian valleys have found evidence of high frequency flood events occurring in the region in recent centuries; further investigations are required to establish if this is the case in the Huab, or whether evidence of events more recent than 600 years ago has been removed from the record by deflation events.

\section{Acknowledgments}

We thank other members of the DO4Models project team for contributions to the framing of this study, particularly Richard Washington, Frank Eckardt and Kate Vickery. Fieldwork for this study was conducted as an additional activity during dust and sediment monitoring studies in 2013 that contributed to both DO4Models, funded by NERC and the Fell Fund (ref121/474), University of Oxford, and the doctoral studies of Andrew Dansie, funded by a Clarendon Scholarship, University of Oxford. Research was carried out under research permit 1788/2013, issued by the Ministry of Environment and Tourism, Namibia. We thank reviewer J-B Stuut and an anonymous reviewer for their helpful comments on the manuscript. 


\section{References}

Bateman, M.D., Frederick, C.D, Jaiswal, M.K., Singhvi, A.K., 2003. Investigations into the potential effects of pedoturbation on luminescence dating. Quaternary Science Reviews 22, 1169-1176.

Bhattachan, A. , D'Odorico, P., Okin, G.S. 2015. Biogeochemistry of dust sources in Southern Africa. Journal of Arid Environments 117, 18-27

Bourke, M.C., Child, A., Stokes, S., 2003. Optical age estimates for hyper-arid fluvial deposits at Homeb,Namibia. Quaternary Science Reviews 22, 1099-1103.

Brook, G.A., Srivastava, P., Marais, E., 2006. Characteristics and OSL minimum ages of relict fluvial deposits near Sossus Vlei, Tsauchab River, Namibia, and a regional climate record for the last $30 \mathrm{ka}$. Journal of Quaternary Science 21, 347-362.

Brunotte, E., Maurer, B., Fischer, P., Lomax, J., Sander, H., 2009. A sequence of fluvial and aeolian deposits (desert loess) and palaeosoils covering the last 60 ka in the Opuwo basin (Kaokoland/Kunene Region, Namibia) based on luminescence dating. Quaternary International 196, 71-85.

Bryant, R.G., 2003. Monitoring hydrological controls on dust emissions: Preliminary observations from Etosha Pan, Namibia. Geographical Journal 169, 131-141.

Bryant, R.G., Bigg, G.R., Mahowald, N.M., Eckardt, F.D., Ross, S.G., 2007. Dust emission response to climate in southern Africa. Journal of Geophysical Research Atmospheres 112, D09207

Bryant, R.G., 2013. Recent advances in our understanding of dust source emission processes. Progress in Physical Geography 37, 397-421. 
Burrough S.L., Thomas D.S.G., Bailey, R.M., 2009 Mega-Lake in the Kalahari. A 250 kyr record of Palaeolake Makgadikgadi. Quaternary Science Reviews 28, 13921411.

Dansie, A., Wiggs, G.F.S., Thomas, D.S.G., 2017a. Iron and nutrient content of winderodible sediment in the dry river valleys of Namibia. Geomorphology,

\section{submitted}

Dansie, A., Thomas, D.S.G. and Wiggs, G.F.S., 2017b. Spatial variability of nutrients in dust-emitting Namibian ephemeral river catchments. Earth Surface Processes and Landforms, submitted.

Dansie, A., Wiggs, G.F.S., Thomas, D.S.G., 2017c. Iron, phosphorus and nitrogen content of deflated sediments from the Namibian ephemeral river valleys and their potential for ocean fertilization. Aeolian research, in prep.

Duller, G.A.T., 2003. Distinguishing quartz and feldspar in single grain luminescence measurements. Radiation Measurements, 37, 161-165.

Durcan, J.A. and Duller, G.A.T., 2011. The fast ratio: a rapid measure for testing the dominance of the fast component in the initial OSL signal from quartz. Radiation Measurements, 46, 1065-1072.

Durcan, J.A., King, G.E., Duller, G.A.T., 2015. DRAC: Dose rate and age calculator for trapped charge dating. Quaternary Geochronology, 28, 54-61.

Eckardt, F.D., Kuring, N.,2005. SeaWiFS identifies dust sources in the Namib Desert(2005) International Journal of Remote Sensing 26, 4159-4167.

Eitel, B., Kadereit, A., Blümel, W.D., Hüser, K., Kromer, B., 2005. The Amspoort Silts, northern Namib desert (Namibia): formation, age and palaeoclimatic evidence of river-end deposits. Geomorphology 64, 299-314. 
Eitel, B., Kadereit, A., Blümel, W.D., Hüser, K., Lomax, J., Hilgers, A., 2006.

Environmental changes at the eastern Namib Desert margin before and after the Last Glacial Maximum: new evidence from fluvial deposits in the upper Hoanib River catchment, northwestern Namibia. Palaeogeography, Palaeoclimatology, Palaeoecology 234, 201-222.

Engelstaedter, S.and Washington, R., 2007. Temporal controls on global dust emissions: The role of surface gustiness. Geophysical Research Letters, 34 art. no. L15805,

Galbraith, R.F. and Green, P.F., 1990. Estimating the component ages in a finite mixture. Nuclear Tracks and Radiation Measurements 17, 197-206.

Galbraith, R.F., Roberts, R.G., Laslett, G.M., Yoshida, H., Olley, J.M., 1999. Optical dating of single and multiple grains of quartz from Jinmium rock shelter, northern Australia: part I, experimental design and statistical models. Archaeometry, 41, 339-364.

Guerin, G., Mercier, N., Adamiec, G., 2011. Dose-rate conversion factors: update. Ancient TL, 29, 5-8.

Greenbaum, N., Schwartz, U., Benito, G., Porat, N., Cloete, G.C, Enzel, Y., 2014. Paleohydrology of extraordinary floods along the Swakop River at the margin of the Namib Desert and their paleoclimate implications. Quaternary Science Reviews 103, 153-169.

Grodek, T., Benito, G., Botero, B.A., Jacoby, Y., Porat, N., Haviv, I., Cloete, G., Enzel, Y., 2014. The lasyt millennium largest floods in the hyperarid Kuiseb basin, Namib Desert. Jopurnal of Quaternary science 28, 258-270. 
Haustein, K., Washington, R., King, J, Wiggs, G, Thomas, D., Menut, L., 2015. Testing the performance of state-of-the-art dust emission schemes using DO4Models field data. Geoscience Models Development 8, 341-362.

Heer, A.J., Adamiec, G., Moska, P., 2012. How many grains are there on a single aliquot? Ancient TL, 30, 9-16.

Hesse, P., McTainsh, G.M., 1999. Last glacial maximum to early Holocene wind strength in the mid-latitudes of the southern hemisphere from aeolian dust in the Tasman Sea. Quaternary Research 52, 343-349.

Hipondoka, M.H.T., Jousse, H., Kempf, J., Busche, D., 2006. Fossil evidence for perennial lake conditions during the Holocene at Etosha Pan, Namibia. South African Journal of Science 102,93-95.

Jacobs, Z., Duller, G.A.T. and Wintle, A.G., 2006. Interpretation of single grain De distributions and calculation of De. Radiation Measurements 41, 264-277.

Jacobson, P.J., Jacobson, K.N., Seely, M.K., 1995. Ephemeral rivers and their catchments: sustaining people and development in western Namibia. Desert Research Foundation of Namibia.

Keiser, L., Soreghan, G.S., Joo, Y.L., 2014. Effects of drying techniques on grainsize analyses of fine grained sediment. Journal of Sedimentary Research 84, 893-896.

Legrand, M., Plana-Fattori, A., N'Doumé, C., 2001. Satellite detection of dust using the IR imagery of Meteosat 1. Infrared difference dust index. Journal of Geophysical Research Atmospheres 106, 18251-18274.

Leighton, C.L., Thomas, D.S.G., Bailey, R.M., 2013. Allostratigrapohy and Quaternary dune sediments: Not all bounding surfaces are the same. Aeolian Research 11, 55-60. 
Marker, M.E., Müller, D., 1978. Relict vlei silts of the Kuiseb River valley, South West Africa. Madoqua 11, 151-162.

Mendez, M.J., Funk, R., Buschiazzo, D.E, 2011. Field wind erosion measurements with Big Spring Number Eight (BSNE) and Modified Wilson and Cook (MWAC) samplers. Geomorphology 129, 43-48.

Morin, E., Grodek, T., Dahan, O., Benito, G., Kulls, C., Jacoby, Y., Van Langenhove, G., Seely, M., Enzel, Y., 2009. Flood routing and alluvial aquifer recharge along the ephemeral arid Kuiseb River, Namibia. Journal of Hydrology 368, 262-275. Murray, A.S.,Roberts, R.G., 1997. Determining the burial time of single grains of quartz using optically stimulated luminescence. Earth and Planetary Science Letters 152, 163-180.

Murray, A.S., Wintle, A.G., 2000. Luminescence dating of quartz using an improved singlealiquot regenerative-dose protocol. Radiation Measurements 32, 57-72.

Olley, J., Caitcheon, G., Murray, A.S., 1998. The distribution of apparent dose as determined by optically stimulated luminescence in small aliquots of fluvial quartz: implications for dating young sediments. Quaternary Science Reviews $17,1033-1040$.

Prescott, J.R., Hutton, J.T., 1994. Cosmic ray contributions to dose rates for luminescence and ESR dating: large depths and long-term time variations. Radiation Measurements 3, 497-500.

Prospero, J.M., Ginoux, P., Torres, S., Nicholson, S., Gill, T., 2002. Environmental characterization of global sources of atmospheric soil dust identified with the Nimbus 7 Total Ozone Mapping Spectrometer (TOMS) absorbing aerosol product. Reviews of Geophysics 40, 1-31 
Rice, M.A., Willetts, B.B., McEwan, I.K. 1996. Observations of collisions of saltating grains with a granular bed from high-speed cine-film. Sedimentology 43, 21-31.

Rodnight, H., Duller, G.A.T., Wintle, A.G., Tooth, S., 2006. Assessing the reproducibility and accuracy of optical dating of fluvial deposits. Quaternary Geochronology 1, 109-120.

Srivastava, P., Brook, G.A., Marais, E., 2004. A Record of fluvial aggradation in the Northern Namib Desert during the Late Quaternary. Zeitschrift fur Geomorphologie, Supplementband 133, 1-18.

Srivastava, P., Brooke, G.A., Marais, E., 2005. Depositional environment and luminescence chronology of the Hoarusib River Clay Castles sediments, northern Namib Desert, Namibia. Catena 59, 187-204.

Srivastava, P., Brook, G.A., Marais, E., Morthekai, P., Singhvi, A.K., 2006.

Depositional environment and OSL chronology of the Homeb silt deposits, Kuiseb River, Namibia. Quaternary Research 65, 478-491.

Stone, A.E.C., Thomas, D.S.G. 2013. Casting new light on late Quaternaryenvironmental and palaeohydrological change in the Namib Desert: A review of the application of optically stimulated luminescence in the region. Journal of Arid Environments 93, 40-58.

Stone, A.E.C., Thomas, D.S.G., Viles, H.A., 2010. Late Quaternary palaeohydrological changes in the northern Namib Sand Sea: new chronologies using OSL dating of interdigitated aeolian and water-lain interdune deposits. Palaeogeography, Palaeoclimatology, Palaeoecology 288, 35-53.

Stuut, J.W., Prins, M.A., Schneider, R.R., Weltje, G.J., Fred Jansen, J.H., Postma, G.,2002. A 300-kyr record of aridity and wind strength in southwestern Africa: 
inferences from grain-size distributions of sediments on Walvis Ridge, SE Atlantic. Marine Geology 180, 221-233.

Stuut, J.B.W., Crosta, X., Schneider, R., van der Borg, K., 2004. Relationship between Antarctic sea ice and southwest African climate during the late Quaternary. Geology 32, 909-912.

Vickery, K.J., 2010. Southern African dust sources as identified by multiple space borne sensors. MSc edn. Department of Environmental and Geographical Science: University of Cape Town.

Vickery, K.J. and Eckardt, F.D. 2013. Dust emission controls on the lower Kuiseb River valley, Central Namib. Aeolian Research 10, 125-133.

Wiggs, G.F.S., O'Hara, S.L., Wegerdt, J., van der Meer, J., Small, I., Hubbard, R., 2003. The dynamics and characteristics of aeolian dust in dryland Central Asia: possible impacts on human exposure and repertory health. Geographical Journal $169,142-157$.

Wintle, A.G., Murray, A.S., 2006. A review of quartz optically stimulated luminescence characteristics and their relevance in single-aliquot regeneration dating protocols. Radiation Measurements, 41, 369-391.

Zobeck, T.M., Sterk, G., Funk, R., Rajot, J.L., Stout, J.E., Van Pelt, R.S. 2003. Measurement and data analysis methods for field-scale wind erosion studies and model validation. Earth Surface Processes and Landforms, 28, 1163-1188. 
Table 1. Dry analysis particle size data (\% contribution) for valley samples

\begin{tabular}{|c|c|c|c|c|c|c|c|c|}
\hline & $\begin{array}{c}\% \text { Very } \\
\text { Coarse - } \\
\text { Medium } \\
\text { Coarse } \\
\text { Sand } \\
(2 \mathrm{~mm}- \\
250 \mu \mathrm{m})\end{array}$ & $\begin{array}{l}\text { \% Fine } \\
\text { Sand } \\
(125- \\
250 \mu \mathrm{m})\end{array}$ & $\begin{array}{l}\% \text { Very } \\
\text { Fine } \\
\text { Sand }(63 \\
-125 \mu \mathrm{m})\end{array}$ & $\begin{array}{c}\% \text { Very } \\
\text { Coarse - } \\
\text { Coarse } \\
\text { Silt } \\
(63 \mu \mathrm{m}- \\
16 \mathrm{~mm})\end{array}$ & $\begin{array}{c}\% \\
\text { Medium- } \\
\text { Fine Silt } \\
(16 \mu \mathrm{m}- \\
4 \mu \mathrm{m})\end{array}$ & $\begin{array}{c}\% \text { Very } \\
\text { Fine Silt } \\
(4 \mu \mathrm{m}- \\
2 \mu \mathrm{m})\end{array}$ & $\begin{array}{l}\text { \% Clay } \\
(<2 \mu \mathrm{m})\end{array}$ & $\begin{array}{c}\text { \%Total } \\
\text { silt }+ \\
\text { very fine } \\
\text { sand }\end{array}$ \\
\hline \multicolumn{9}{|l|}{ H2 Transect Samples } \\
\hline Fill Surface & 36.52 & 30.45 & 22.20 & 7.22 & 3.29 & 0.32 & 0.00 & 33.03 \\
\hline Fill $(-10 \mathrm{~cm})$ & 28.52 & 41.20 & 21.01 & 6.61 & 2.66 & 0.10 & 0.00 & 30.38 \\
\hline Inner channel terrace & 37.30 & 48.11 & 13.16 & 1.03 & 0.40 & 0.00 & 0.00 & 14.59 \\
\hline Channel floor & 86.04 & 12.70 & 1.08 & 0.18 & 0.00 & 0.00 & 0.00 & 1.26 \\
\hline \multicolumn{9}{|l|}{ Dated valley fill samples } \\
\hline Huab13/1/1 & 35.19 & 43.60 & 14.90 & 5.46 & 0.86 & 0.00 & 0.00 & 21.22 \\
\hline Huab13/1/2 & 25.85 & 21.95 & 23.40 & 13.90 & 12.58 & 3.88 & 2.32 & 53.76 \\
\hline Huab13/1/3 & 38.21 & 53.87 & 7.91 & 0.00 & 0.00 & 0.00 & 0.00 & 7.91 \\
\hline Huab13/1/4 & 56.84 & 38.42 & 4.75 & 0.00 & 0.00 & 0.00 & 0.00 & 4.75 \\
\hline Huab13/1/5 & 60.63 & 35.68 & 3.69 & 0.00 & 0.00 & 0.00 & 0.00 & 3.69 \\
\hline Huab13/1/6 & 97.61 & 2.39 & 0.00 & 0.00 & 0.00 & 0.00 & 0.00 & 0.00 \\
\hline Huab13/2/1 & 26.24 & 52.52 & 18.98 & 2.07 & 0.19 & 0.00 & 0.00 & 21.24 \\
\hline Huab13/2/2 & 75.52 & 22.93 & 1.55 & 0.00 & 0.00 & 0.00 & 0.00 & 1.55 \\
\hline Huab13/2/3 & 43.67 & 48.63 & 7.70 & 0.00 & 0.00 & 0.00 & 0.00 & 7.70 \\
\hline
\end{tabular}


Table 2. Dry analysis Particle size data (\% contribution) for BSNE samples

\begin{tabular}{|c|c|c|c|c|c|c|c|c|c|}
\hline $\begin{array}{l}\text { Sample } \\
\text { collection } \\
\text { date }\end{array}$ & BSNE & $\begin{array}{l}\% \text { Very } \\
\text { Coarse - } \\
\text { Medium } \\
\text { Coarse } \\
\text { Sand } \\
(2 \mathrm{~mm}- \\
250 \mu \mathrm{m})\end{array}$ & $\begin{array}{l}\% \text { Fine } \\
\text { Sand } \\
(125- \\
250 \mu \mathrm{m})\end{array}$ & $\begin{array}{l}\% \text { Very } \\
\text { Fine } \\
\text { Sand (63 } \\
-125 \mu \mathrm{m})\end{array}$ & $\begin{array}{c}\text { \% Very } \\
\text { Coarse - } \\
\text { Coarse } \\
\text { Silt } \\
(63 \mu \mathrm{m} \text { - } \\
16 \mathrm{~mm})\end{array}$ & $\begin{array}{c}\% \\
\text { Medium- } \\
\text { Fine Silt } \\
(16 \mu \mathrm{m}- \\
4 \mu \mathrm{m})\end{array}$ & $\begin{array}{c}\% \text { Very } \\
\text { Fine Silt } \\
(4 \mu \mathrm{m}- \\
2 \mu \mathrm{m})\end{array}$ & $\begin{array}{l}\text { \% Clay } \\
(<2 \mu \mathrm{m})\end{array}$ & $\begin{array}{c}\% \text { Total } \\
\text { silt }+ \\
\text { very fine } \\
\text { sand }\end{array}$ \\
\hline \multirow{4}{*}{$29 / 05 / 13$} & 1 & 42.51 & 24.45 & 24.25 & 6.61 & 2.18 & 0.00 & 0.00 & 33.04 \\
\hline & 2 & 12.05 & 27.75 & 41.98 & 14.08 & 3.58 & 0.57 & 0.56 & 60.21 \\
\hline & 3 & 1.05 & 25.76 & 47.54 & 20.47 & 4.54 & 0.70 & 0.64 & 73.25 \\
\hline & 4 & 2.79 & 23.25 & 46.34 & 22.31 & 4.69 & 0.71 & 0.62 & 74.05 \\
\hline \multirow{4}{*}{ 07/07/13 } & 1 & 31.36 & 33.36 & 27.31 & 5.81 & 2.16 & 0.07 & 0.00 & 35.35 \\
\hline & 2 & 13.22 & 33.81 & 38.34 & 11.19 & 3.43 & 0.44 & 0.00 & 53.40 \\
\hline & 3 & 2.17 & 26.16 & 46.48 & 20.08 & 4.50 & 0.71 & 0.62 & 71.77 \\
\hline & 4 & 0.04 & 23.53 & 48.07 & 22.91 & 4.81 & 0.73 & 0.64 & 76.52 \\
\hline \multirow{4}{*}{ 01/08/13 } & 1 & 43.60 & 25.24 & 23.49 & 5.98 & 1.70 & 0.00 & 0.00 & 31.17 \\
\hline & 2 & 12.07 & 28.57 & 41.86 & 14.10 & 2.90 & 0.45 & 0.50 & 59.31 \\
\hline & 3 & 2.48 & 26.23 & 47.45 & 19.65 & 3.60 & 0.55 & 0.59 & 71.25 \\
\hline & 4 & 0.91 & 23.81 & 48.03 & 22.90 & 3.77 & 0.55 & 0.59 & 75.25 \\
\hline \multirow{4}{*}{$\begin{array}{l}\text { Collection } \\
\text { means }\end{array}$} & 1 & 39.15 & 27.68 & 25.02 & 6.13 & 2.01 & 0.02 & 0.00 & 33.18 \\
\hline & 2 & 12.45 & 30.04 & 40.73 & 13.13 & 3.31 & 0.49 & 0.35 & 57.66 \\
\hline & 3 & 1.90 & 26.05 & 47.16 & 20.06 & 4.22 & 0.66 & 0.61 & 72.10 \\
\hline & 4 & 1.25 & 23.53 & 47.48 & 22.71 & 4.42 & 0.66 & 0.62 & 75.27 \\
\hline
\end{tabular}

This article is protected by copyright. All rights reserved. 
Table 3. Wet analysis (disaggregated) particle size data (\% contribution) for selected samples

\begin{tabular}{|c|c|c|c|c|c|c|c|c|c|}
\hline & & $\begin{array}{l}\% \text { Very } \\
\text { Coarse - } \\
\text { Medium } \\
\text { Coarse } \\
\text { Sand } \\
(2 \mathrm{~mm}- \\
250 \mu \mathrm{m})\end{array}$ & $\begin{array}{l}\text { Fine } \\
\text { Sand } \\
(125- \\
250 \mu \mathrm{m})\end{array}$ & $\begin{array}{l}\text { \% Very } \\
\text { Fine } \\
\text { Sand }(63 \\
-125 \mu \mathrm{m})\end{array}$ & $\begin{array}{c}\% \text { Very } \\
\text { Coarse - } \\
\text { Coarse } \\
\text { Silt } \\
(63 \mu \mathrm{m}- \\
16 \mathrm{~mm})\end{array}$ & $\begin{array}{c}\% \\
\text { Medium- } \\
\text { Fine Silt } \\
(16 \mu \mathrm{m}- \\
4 \mu \mathrm{m})\end{array}$ & $\begin{array}{c}\% \text { Very } \\
\text { Fine Silt } \\
(4 \mu \mathrm{m}- \\
2 \mu \mathrm{m})\end{array}$ & $\begin{array}{l}\text { \% Clay } \\
(<2 \mu \mathrm{m})\end{array}$ & $\begin{array}{c}\text { \%Total } \\
\text { silt }+ \\
\text { very fine } \\
\text { sand }\end{array}$ \\
\hline \multicolumn{10}{|c|}{ H2 Transect Samples } \\
\hline \multicolumn{2}{|c|}{ Fill Surface } & 3.14 & 9.42 & 11.69 & 24.82 & 33.58 & 9.65 & 7.69 & 79.74 \\
\hline \multicolumn{2}{|c|}{ Fill $(-10 \mathrm{~cm})$} & 1.92 & 6.73 & 10.41 & 22.49 & 37.37 & 11.97 & 9.10 & 82.24 \\
\hline \multicolumn{2}{|c|}{ Inner channel terrace } & 9.48 & 20.68 & 19.45 & 27.02 & 14.98 & 4.18 & 4.20 & 65.63 \\
\hline \multicolumn{2}{|c|}{ Channel floor } & 46.95 & 19.81 & 4.08 & 8.27 & 13.65 & 3.94 & 3.31 & 29.94 \\
\hline \multicolumn{10}{|c|}{ Dated valley fill samples } \\
\hline \multicolumn{2}{|c|}{ Huab13/1/1 } & 29.87 & 38.20 & 16.85 & 8.78 & 3.95 & 1.24 & 1.11 & 30.82 \\
\hline \multicolumn{2}{|c|}{ Huab13/1/4 } & 43.74 & 36.12 & 9.06 & 3.66 & 4.20 & 1.66 & 1.56 & 18.58 \\
\hline \multicolumn{2}{|c|}{ Huab13/1/6 } & 90.77 & 3.00 & 0.53 & 1.32 & 2.05 & 1.03 & 1.31 & 5.93 \\
\hline \multicolumn{10}{|c|}{ Dust } \\
\hline \multirow{4}{*}{$\begin{array}{l}\text { BSNE } \\
\text { collection } \\
\text { means }\end{array}$} & 1 & 7.01 & 17.91 & 30.80 & 20.55 & 12.90 & 5.16 & 5.67 & 69.46 \\
\hline & 2 & 2.07 & 12.27 & 36.19 & 28.94 & 11.39 & 4.18 & 4.95 & 80.70 \\
\hline & 3 & 0.00 & 7.69 & 35.71 & 36.50 & 11.58 & 3.81 & 4.71 & 87.60 \\
\hline & 4 & 0.00 & 6.98 & 34.99 & 38.39 & 11.38 & 3.68 & 4.58 & 88.44 \\
\hline
\end{tabular}

This article is protected by copyright. All rights reserved. 
Table 4. OSL age data. Equivalent doses, dose rates, and ages are shown to two decimal places. All calculations were made prior to rounding

\begin{tabular}{|c|c|c|c|c|c|c|c|c|c|c|}
\hline $\begin{array}{c}\text { Sample } \\
\text { (Huab) }\end{array}$ & $\begin{array}{l}\text { Depth } \\
\text { (m) }\end{array}$ & $\begin{array}{c}\text { Grain size } \\
\qquad(\mu \mathrm{m})\end{array}$ & $\mathrm{n}^{\mathrm{a}}$ & $\sigma_{d}(\%)^{b}$ & $D_{e}(G y)^{c}$ & $\begin{array}{c}\text { Beta dose rate } \\
\left(G y \cdot \mathrm{ka}^{-1}\right)\end{array}$ & $\begin{array}{c}\text { Gamma dose } \\
\text { rate } \\
\left(\text { Gy.ka }^{-1}\right)\end{array}$ & $\begin{array}{c}\text { Cosmic } \\
\text { dose rate } \\
\left(G_{y} \cdot \mathrm{ka}^{-1}\right)\end{array}$ & $\begin{array}{c}\text { Environmental } \\
\text { dose rate } \\
\left(G_{y} \cdot \mathrm{ka}^{-1}\right)\end{array}$ & Age (ka) \\
\hline $13 / 1 / 1$ & 0.3 & $180-210$ & $40(23)$ & $55 \pm 7$ & $2.23 \pm 0.16$ & $1.81 \pm 0.14$ & $1.03 \pm 0.07$ & $0.19 \pm 0.02$ & $3.04 \pm 0.16$ & $0.73 \pm 0.07$ \\
\hline $13 / 1 / 2$ & 0.7 & $125-150$ & 40 (33) & $37 \pm 3$ & $1.86 \pm 0.07$ & $1.84 \pm 0.17$ & $1.06 \pm 0.12$ & $0.18 \pm 0.02$ & $3.08 \pm 0.22$ & $0.60 \pm 0.03$ \\
\hline $13 / 1 / 3$ & 1.5 & $180-210$ & $40(23)$ & $51 \pm 6$ & $6.18 \pm 0.45$ & $1.79 \pm 0.14$ & $1.05 \pm 0.08$ & $0.17 \pm 0.02$ & $3.01 \pm 0.16$ & $2.05 \pm 0.18$ \\
\hline $13 / 1 / 4$ & 2.0 & $180-210$ & $24(21)$ & $47 \pm 6$ & $8.53 \pm 0.79$ & $1.63 \pm 0.13$ & $0.86 \pm 0.06$ & $0.15 \pm 0.02$ & $2.64 \pm 0.15$ & $3.24 \pm 0.35$ \\
\hline $13 / 1 / 5$ & 2.8 & $180-210$ & $24(24)$ & $44 \pm 5$ & $10.28 \pm 0.50$ & $1.42 \pm 0.11$ & $0.77 \pm 0.05$ & $0.14 \pm 0.01$ & $2.33 \pm 0.13$ & $4.41 \pm 0.32$ \\
\hline $13 / 1 / 6$ & 3.6 & $180-210$ & $24(19)$ & $14 \pm 2$ & $23.68 \pm 1.14$ & $1.50 \pm 0.12$ & $0.79 \pm 0.06$ & $0.12 \pm 0.01$ & $2.42 \pm 0.14$ & $9.79 \pm 0.73$ \\
\hline $13 / 2 / 1$ & 0.3 & $180-210$ & $44(38)$ & $73 \pm 7$ & $2.80 \pm 0.14$ & $2.54 \pm 0.19$ & $1.81 \pm 0.15$ & $0.19 \pm 0.02$ & $4.54 \pm 0.24$ & $0.62 \pm 0.04$ \\
\hline $13 / 2 / 2$ & 0.5 & $180-210$ & $48(33)$ & $98 \pm 1$ & $1.49 \pm 0.10$ & $1.37 \pm 0.12$ & $0.67 \pm 0.05$ & $0.19 \pm 0.02$ & $2.23 \pm 0.13$ & $0.67 \pm 0.06$ \\
\hline $13 / 2 / 3$ & 1.0 & $180-210$ & $38(34)$ & $97 \pm 1$ & $3.82 \pm 0.16$ & $1.70 \pm 0.14$ & $0.87 \pm 0.06$ & $0.18 \pm 0.02$ & $2.74 \pm 0.16$ & $1.39 \pm 0.10$ \\
\hline
\end{tabular}

${ }^{a}$ The number of measured aliquots is shown, with the number of aliquots passing all rejection criteria and used in age calculation shown in parentheses.

${ }^{\mathrm{b}} \sigma_{d}$ refers to the overdispersion parameter of Galbraith et al., (1999) used to assess the dose distributions.

${ }^{c}$ The finite mixture model was used for $D_{e}$ determination for all samples, except HUAB-13-1-6 where the central age model was applied. 


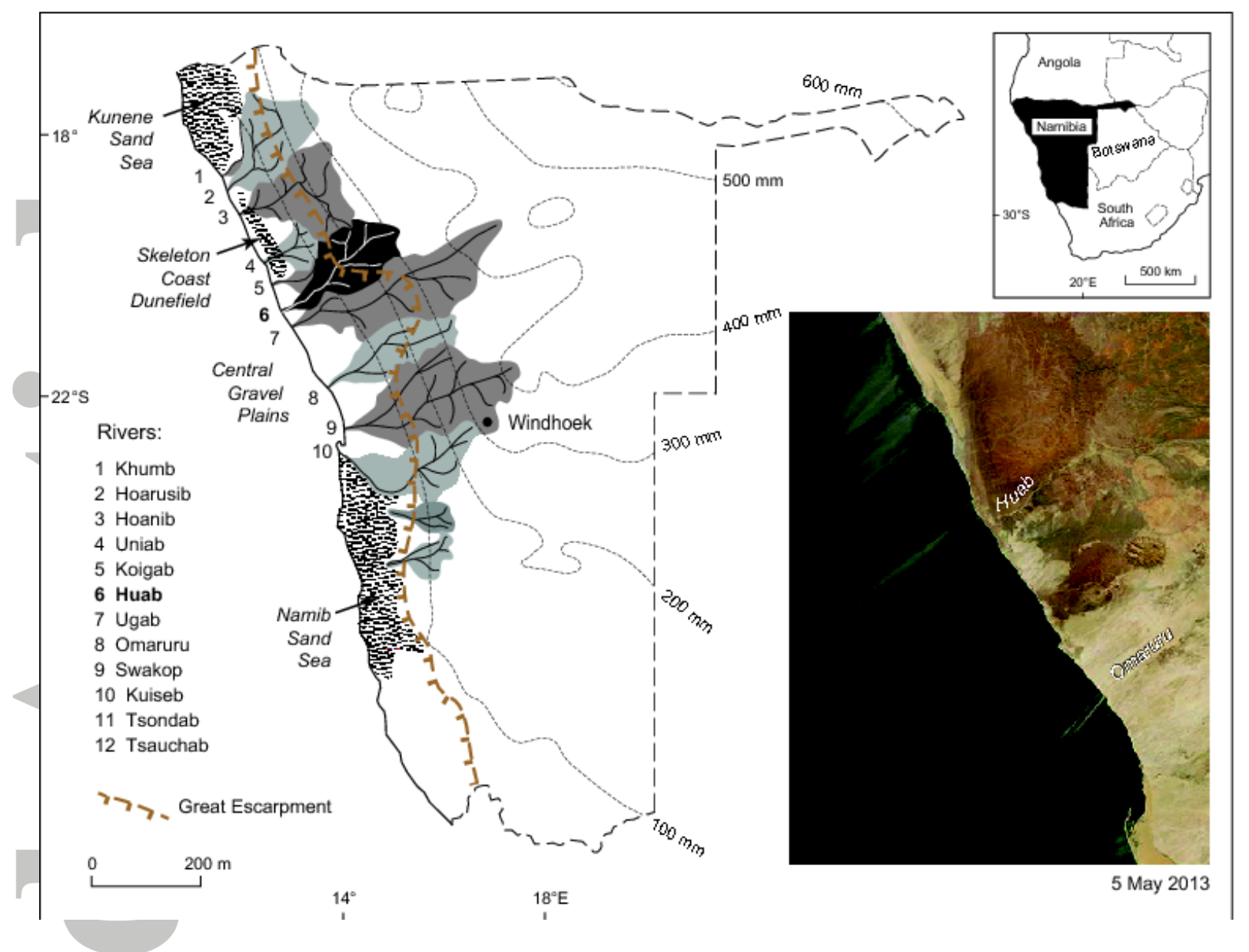

Figure 1. West coast valleys and channel systems of Namibia. Catchments, principle channels, desert sand seas and mean annual isohyets are shown. The Huab catchment is highlighted. Inset MODIS image of dust plumes extending over the Atlantic Ocean on 5 May 2013. The Huab is the source of a particularly extensive plume. 


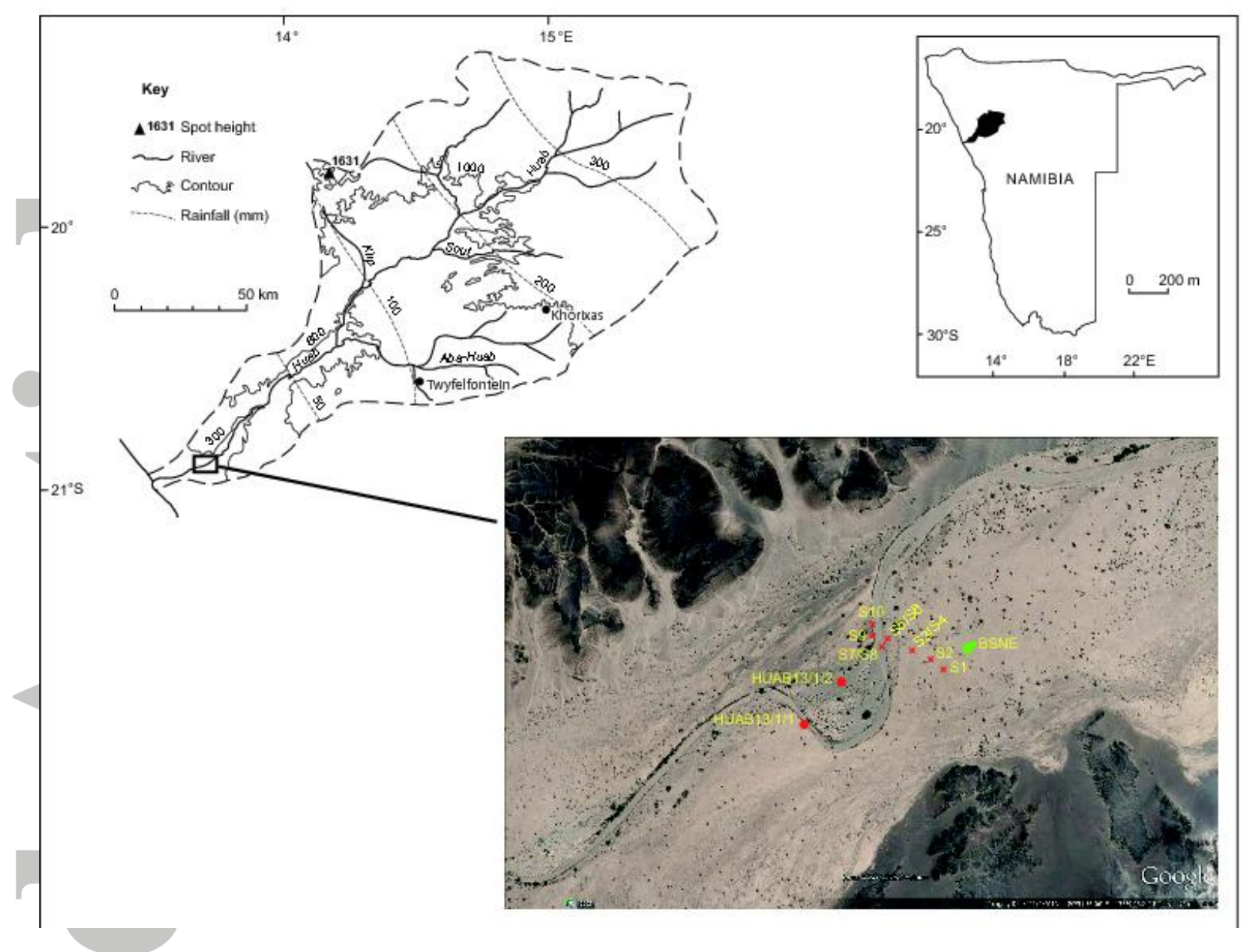

Figure 2. The Huab system showing the location of sediment sample sites used in this paper. Huab13/1 and 13/2 refer to the valley fill sections where samples were collected for OSL dating and S locations refer to the surface samples where S1, S2 and S3 are fill surface samples, S4 is a 10cm depth subsurface sample, S5 and S6 are from the surface of an inner channel terrace and S7, S8, S9 and S10 are modern channel floor samples). The location of the BSNE sampler is also shown. 


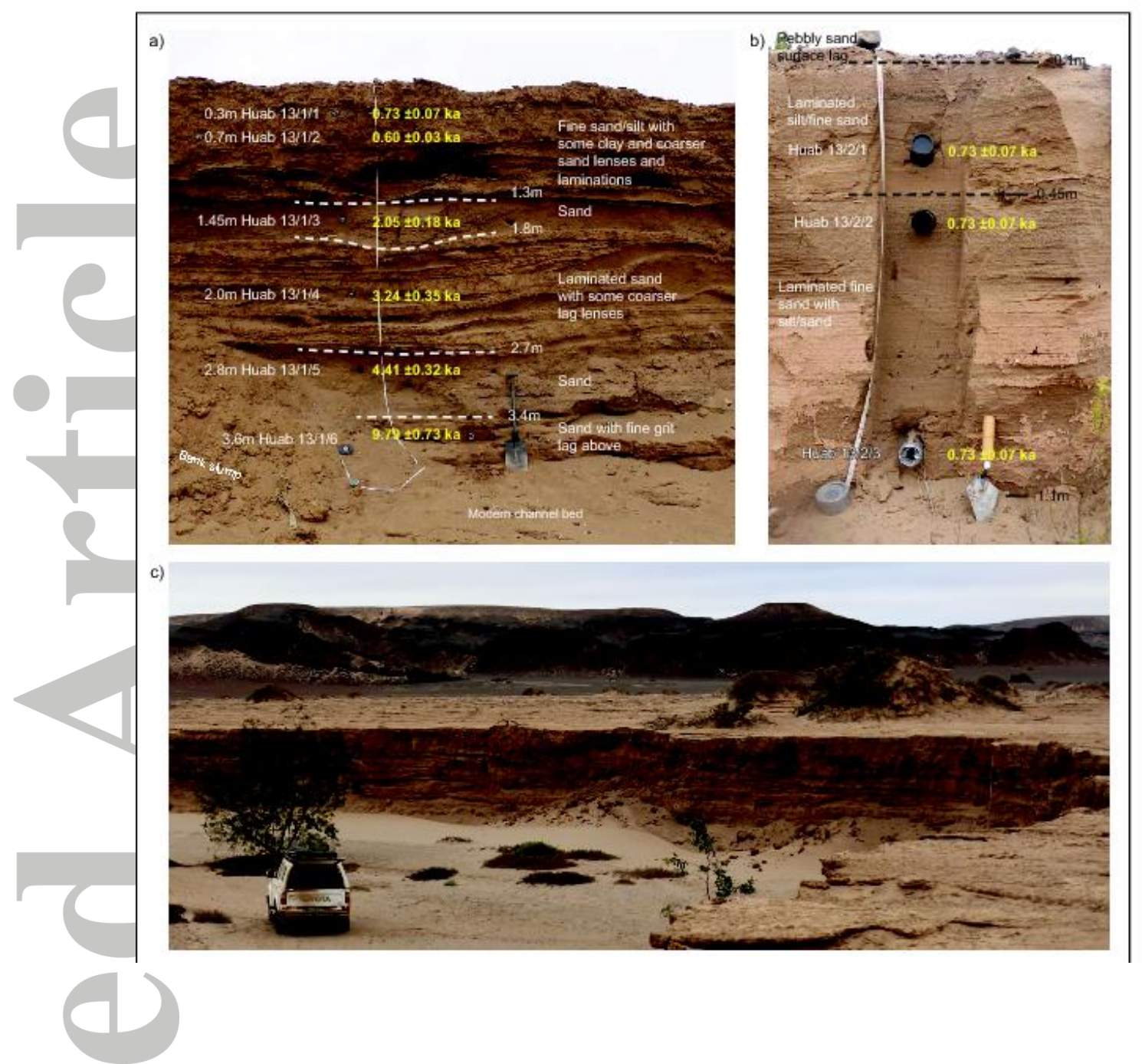

Figure 3. Valley fill sample sites Huab13/1 (a) and Huab13/2 (b). See Figure 2 for locations. c) shows the main channel incision and exposure of valley fill sediments, with nebkha dunes on the upper fill surface in the right of the photograph.

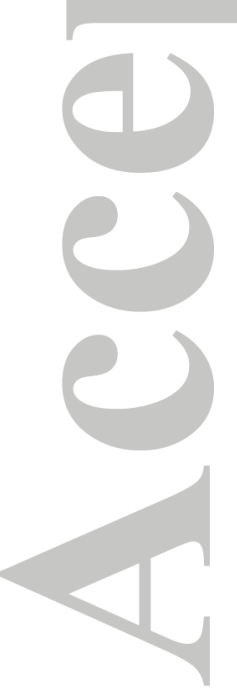

This article is protected by copyright. All rights reserved. 


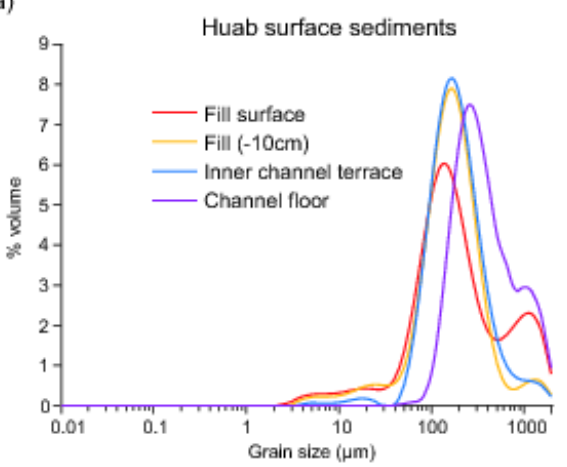

c)
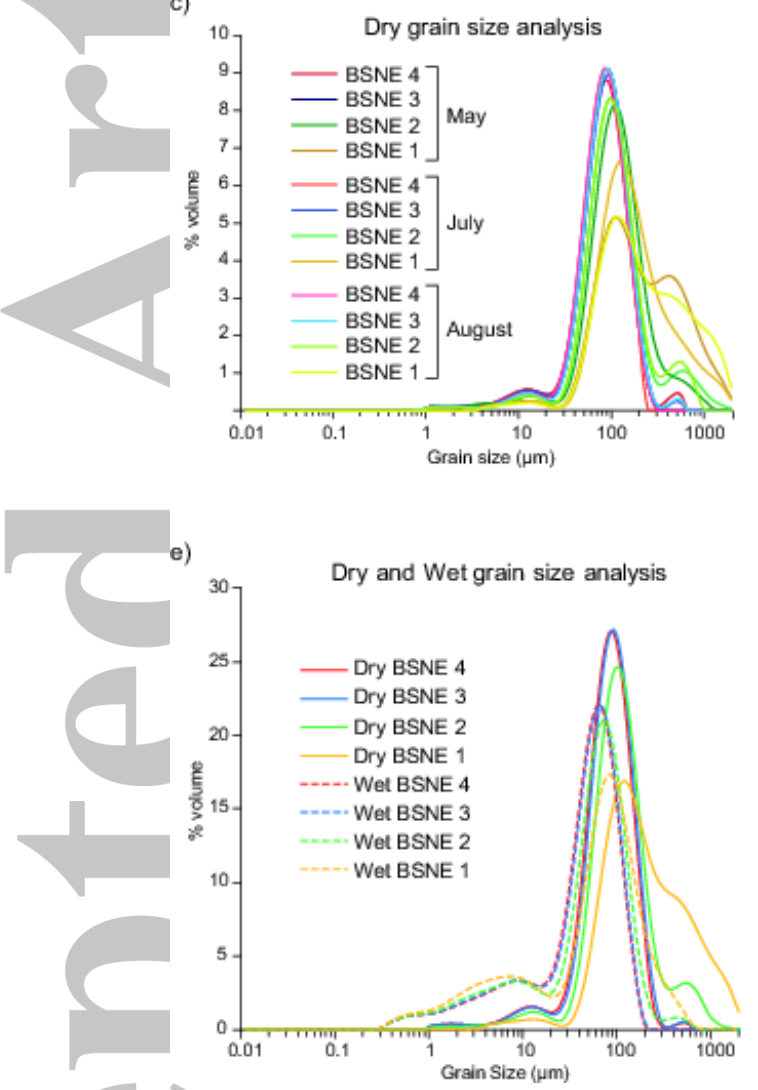

b)

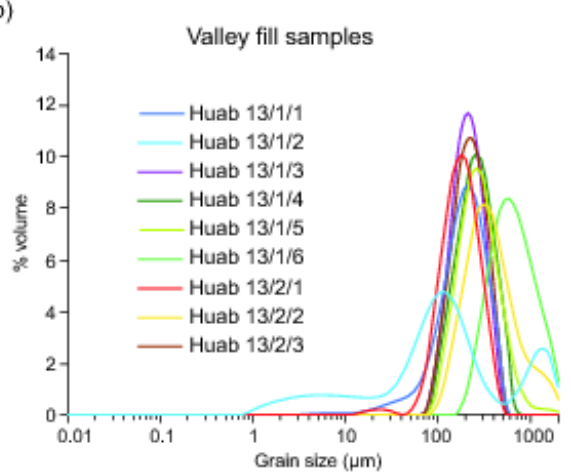

d)
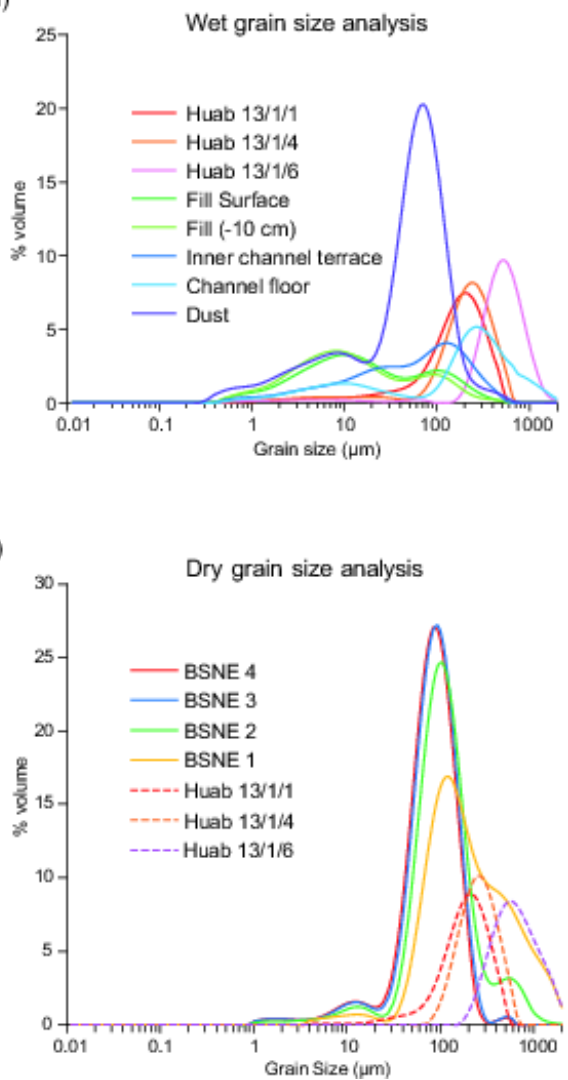

Figure 4. Sediment grain size data for a) surface samples, b) samples from the dated valley fill sections, and c) BSNE sediment samplers, with data displayed both by sampler height and by sampling date (see text and Table 1). d) Representative wet-analysed samples from the surface, valley fill and BSNE sampler mean values.

e) BSNE data from all trap heights plotted as both wet and dry dispersal data. 

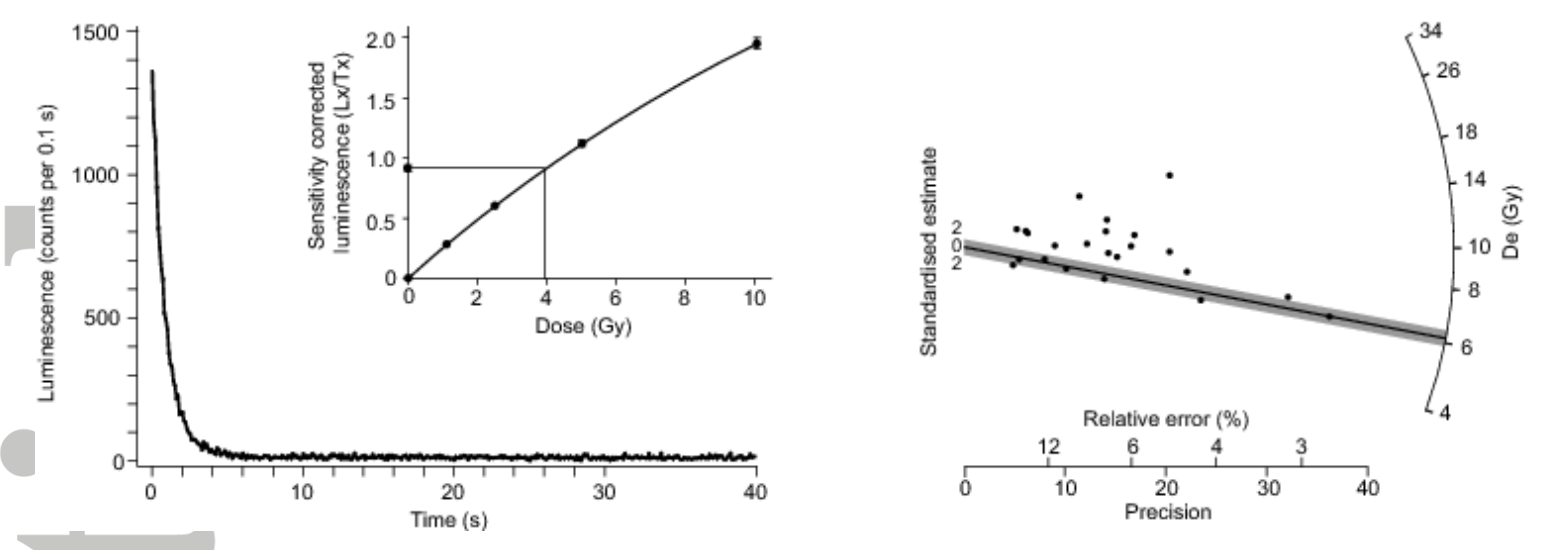

Figure 5. a) An example OSL signal and inset, the dose response for an aliquot of sample Huab13/1/3. The dose response curve has been fitted with an exponential function and that natural, sensitivity corrected luminescence signal (shown by the grey symbol) has been interpolated to give $a D_{e}$ of $6.87 \mathrm{~Gy}$. b) The dose distribution for the same sample. All points within the grey shaded area are within approximately $2 \sigma$ of the $6.18 \mathrm{~Gy} \mathrm{D}_{\mathrm{e}}$ (shown by the solid line). 